\title{
Optimization of gluten free biscuit from foxtail, copra meal and amaranth
}

\author{
Singh AJAY ${ }^{1 *}$, Kumar PRADYUMAN ${ }^{1}$
}

\begin{abstract}
Optimization of proportion for minimally processed foxtail millet flour (FMF) (55g or 85\%) and copra meal flour (CMF) $(10 \mathrm{~g}$ or $15 \%)$ through preliminary trials were done sensorially to have gluten free premix. Optimized premix $(60 \mathrm{~g}$ or $60 \%)$ work upon further with amaranth flour $(\mathrm{AF})(40 \mathrm{~g}$ or $40 \%)$ in the same way to have gluten free composite mix that works as base material. Further selected independent variables i.e. AF (30-40g/100g premix), fat (35-42 g/100g composite mix) and skim milk powder (SMP) (4-6g/100g composite mix) were used for standardization of ingredients level to formulate biscuits through central composite rotatable design (CCRD) of response surface methodology (RSM). Numerically optimized formulation were found to $40 \mathrm{~g} / 100 \mathrm{~g}, 4 \mathrm{~g} / 100 \mathrm{~g}$ and $42 \mathrm{~g} / 100 \mathrm{~g}$ values were optimized for AF, SMP and fat respectively using series of responses viz. maximum spread ratio, fiber content, overall acceptability and with minimum of breaking strength values. Resultant biscuit was shown to have favorable characteristics of overall acceptability (7.55) with desirable responses (0.794) for celiacs.
\end{abstract}

Keywords: biscuit; copra; dried milk; gluten intolerant; gluten free grain; optimization modeling.

Practical Application: This project searches the possibility for formulation of pseudocereal, coarse cereal and coconut industry waste to have a baked gluten free diet. The underutilized varieties of selected ingredients are in easy access to every income population with enhanced health attributes owe to fiber richness. Inclusion of skim milk powder (protein) alongwith amaranth meant to elevate protein profile. Here, minimal home scale pre-processing aspect of millets is needed to avoid anti-nutrients and justified tannin values as per human concern resulted in an option for hunger and malnourished celiac sufferers with cheap access. Nutraceutical properties of copra meal along with other ingredients tune the developed product as potential functional food for future to promote immunity, antihistamines and antiseptics.

\section{Introduction}

Biscuits are the largest consumable snacks, consumed globally since long for nutritional requirement, enjoyment, gift and in high spirit as well (Srivastava., 2010) According to classification, these are the eatables with elevated fat and sugar level but with lesser quantity of water (Lai \& Lin, 2006). Their varied proportion (\%) form the basis to decide their name i.e. cookies or biscuits. No doubt, these are nutritious and appealing but blind inclusion of high fat (saturated), sugar (sucrose) and wheat flour as base ingredients make it as unhealthy choice for obese, diabetic and celiac sufferers respectively. Also, high fat and sugar can be enjoyed occasionally but celiacs have to restrict gluten (wheat protein) free diet throughout lifetime (Valentina et al., 2010). Avoidance of wheat flour in Indian community is a big challenge and brainstorming matter where list of wheat based pan leavened bread i.e. Chapati, Parantha, Poori, Kulcha, Bhatura, Naan and Missi roti consumed throughout the day as a part of staple diet by all income group inhabitants of any age. It comprises gluten protein as responsible component that triggers immune responses (nausea, vomitting, rashes, redness of face, running eyes and abdominal cramps) in gluten intolerant patients on consumption. It is also evident from the recent statistics that prevalence of celiac disease in northern community of India is 1 among 96 (Makharia et al., 2011). Hence, there is a need for range of gluten free products as healthy demand for gluten intolerant to have easy lifelong sustainability. This, entire scenario prompted food scientists to design potentially nutritive, gluten-free alternate with some functional characteristics that are in easy access to all.

Inclusion of health promoting factors or replacement of unhealthy ingredients in preparation of frequently consumed meal is the only mean to add functional characteristics in eatables (Gallagher et al., 2004). Selection of gluten free flour is a wise choice now a days to combat with celiacs. This functionality can be extended favorably by replacing saturated bakery fat proportion, table sugar proportion with various healthy components alongwith fiber supplementation, protein enrichment and minerals fortification etc (Siró et al., 2008). It is evident by various researchers concern that coarse cereals, pseudocereals and by-products works as "animal fodder" are nutritious and convenient enough if utilized under the heading "human feed" (Saturni et al., 2010). Moreover, they are nutritionally superior to staple cereals i.e. rice and wheat which make it suitable for industrial scale utilization for food preparation like baby food, composite dairy mix, snack food and other dietary stuffs. Foxtail millet (Setaria italica) is among them that works to enrich prepared eatables with its dietary fiber (Kim et al., 2011), divalent 
cation minerals $\left(\mathrm{Ca}^{2+}, \mathrm{Mg}^{2+}\right.$ and $\mathrm{Zn}^{2+}$ ) with low glycemic index characteristics (Anju \& Sarita, 2010). It is high in polyphenolics (Awika \& Rooney, 2004) that prevents cardiovascular disease and elevate our immune system. Similarly pseudocereals are the key target of researchers especially Amaranth (Amaranthus spp.) having prime importance owe to its high protein uniqueness with significantly elevated lysine content (Bressani \& Garcia-Vela, 1990) among gluten free grain. Amaranth loaded with unsaturated fat; approximately $77 \%$ polyunsaturated fatty acids (Whelton et al., 1997) with its wildly grown capacities allow consumers for its easy and cheap availability round the year. In the same sense by-product or industrial waste (cheese or paneer whey, copra meal and fruit pomace) works as gluten free ingredients, generally ignored or discarded unknowingly. Copra meal flour from coconut industry obtained after oil extraction of dried desiccated coconut (Cocos nucifera L.) which is completely gluten free. It controls cholesterol, blood sugar and retricts colon cancer with its high fiber content (Arancon, 1999). Besides these properties, short and medium chain fatty acids present in coconut meals shows nutraceutical effects in terms of immunity enhancer, antihistamines and antiseptics (Moorthy \& Visswanathan, 2009). So selection of foxtail, amaranth and copra meal flour as base material, optimized wisely to present a value added biscuits with enhanced health attributes and as functional food. As gluten imparts favorable characteristics of binding to all constituents of prepared dough thus maintain consistency. But sheeting of gluten free dough, opposes the convenience in manual handling and machinability thus visco-elastic properties in dough to get suitable baked stuffs can be counter balanced by hydrocolloid addition viz. guar gum, xanthan gum (Curic et al., 2007) that ended in polymerized mass and ready to bake (Achayuthakan \& Suphantharika, 2008).

Initially, gluten free biscuit was prepared through preliminary selection of level of ingredients (Table 1) to obtain gluten free composite mix (foxtail millet flour, copra meal flour and amaranth flour). Composite mix characterized further in terms of fat and SMP alongwith refined range of amaranth as independent variable in baked samples which was investigated through central composite rotatable design (Design expert DX7) to get optimized product.

\section{Materials and methods}

Foxtail millet variety DHFT 109-3 was procured from one of the trader of Guntoor district of Telangana (India). It is then treated to make it dust free through sequential steps of washing, drying and then allowed to soak in potable running water overnight at room temperature. Soaked grains were allowed to germinate on incubation in moist condition over muslin cloth bedded plastic tray at $25^{\circ} \mathrm{C}$ for $48-72 \mathrm{~h}$ (Singh \& Kumar, 2018). Germinated grains were then tray dried followed with hand rubbing against perforated aluminium tray to remove dried rootlets. Milling of grains was done separately (germinated grain flour and rootlets flour). White variety of Amaranthus hypochondriacus (amaranth seeds) were purchased in commercial grade packing of $250 \mathrm{~g}$ from M/s. Gaur Traders, Kurukshetra, Haryana (India). Cleaned dried seeds were then subjected to dry milling to get flour. Likewise copra meal was procured from Santhosh Oil Mills of Kannur Kerala. Obtained flakes were pulverized to flour for present project work.

\subsection{Preliminary study for preparation of biscuit}

Test biscuits were prepared with utmost level of foxtail millet flour (FMF) owe to recognize them as millet biscuit and by varying copra meal flour (CMF) from 0 to $25 \mathrm{~g}$ in predetermined sequential steps to form premix and evaluated sensorially (Table 1). A combination of FMF and CMF of $55 \mathrm{~g}$ $(\sim 85 \%)$ and $10 \mathrm{~g}(\sim 15 \%)$ was selected on the basis of sensory evaluation (data not shown). Proportion of this standardized premix was then optimized with amaranth flour (AF) as varied ( $15 \mathrm{~g}$ to $40 \mathrm{~g} / 100 \mathrm{~g}$ ) which is found to be appropriate at $40 \mathrm{~g} / 100 \mathrm{~g}$ on the basis of sensory evaluation (data not shown).

\subsection{Biscuits preparation}

Previously optimized base materials were also tested for other key factors as of prime importance i.e. fat and skim milk powder (SMP) to govern sensory (appearance and mouthfeel) and physical (spread factor and cutting and binding capacity) characteristics in gluten free network thus work as independent variable. Remaining fixed ingredients to each experiment were; sugar powder (32g), salt, baking powder and guar gum (1g each), ammonium bicarbonate $(0.75 \mathrm{~g})$ along with water $(22.5 \mathrm{ml} / 100 \mathrm{~g})$ in composite flour. Preparation of dough for biscuit initiated with bakery fat and sugar powder creaming in hobart mixer (Shakti Model XB-5L, India) at speed of $\sim 61 \mathrm{rpm}$ (1 min) during creaming and continued to $\sim 178 \mathrm{rpm}$ (3 min). Luke warm water $\left(42-45^{\circ} \mathrm{C}\right)$ dissolved gel of guar gum was poured on to the creamed mass (Hathan \& Prassana, 2011) followed with water dissolved ammonium bicarbonate $(0.75 \%)$ and sodium chloride (1\%) and then mixed for about $4 \mathrm{~min}$. Prepared dough was then sheeted to $1 \mathrm{~cm}$ thickness with wooden rolling pin and cut with the aid of circular biscuit cutter of $5 \mathrm{~cm}$ diameter and baked at $180^{\circ} \mathrm{C}$ for $15 \mathrm{~min}$. Baked samples were allowed to cool for $20 \mathrm{~min}$ (Room temperature $15^{\circ} \mathrm{C}$ ) and then packed in 150 gauge high density polyethylene laminates.

Table 1. Proportion of variables used in preliminary trials for biscuit preparation.

\begin{tabular}{|c|c|c|c|c|c|c|c|c|}
\hline \multirow{2}{*}{$\begin{array}{l}\text { Sr No. } \\
\text { Trial-1 }\end{array}$} & \multirow{2}{*}{$\begin{array}{c}\text { Type of Mix } \\
\text { Premix (g) }\end{array}$} & \multirow{2}{*}{$\begin{array}{c}\text { Name of flour } \\
\text { Foxtail millet flour }\end{array}$} & \multicolumn{6}{|c|}{ Preliminary steps to develop composite mix (g) } \\
\hline & & & 55 & 55 & 55 & 55 & 55 & 55 \\
\hline \multirow{3}{*}{ Trial-2 } & & Copra meal flour & 25 & 20 & 15 & 10 & 5 & 0 \\
\hline & Composite Mix (g) & Premix flour & 60 & 65 & 70 & 75 & 80 & 85 \\
\hline & & Amaranth flour & 40 & 35 & 30 & 25 & 20 & 15 \\
\hline
\end{tabular}




\subsection{Experimental design for optimization of formulation}

Central composite rotatable design (CCRD) of response surface methodology (RSM) was applied over the pre-decided ranges, screened in preliminary trials (Table 1). Fat, SMP and amaranth counted as independent variable against selected traits (spread ratio, fiber, hardness and overall acceptability) to get much refined product. Fat and SMP proportion of the selected recipe was varied from $(38 \pm 4 \%)$ and $(5 \pm 1 \%)$ respectively on the basis of literature to find better acceptability of gluten free biscuits. Similarly amaranth flour was varied between $30-40 \%$. Total experiments were composed of 8 factorial runs, 6 central runs and 6 axial run. Low and high levels of independent variables were 30 and $40 \mathrm{~g}$ for AF in $100 \mathrm{~g}$ premix, 4 and $6 \mathrm{~g} / 100 \mathrm{~g}$ SMP in composite mix; 34 and $42 \mathrm{~g} / 100 \mathrm{~g}$ fat in composite mix (Table 2). RSM selection as statistical modeling tool over independent variables aimed to develop a product with maximum spread ratio, fiber content, and overall acceptability with minimum breaking strength as dependent variable. Experiments were conducted randomly to minimize the effects of unexplained variability in observed responses due to external factors (Table 3). Second order polynomial equation fitted to experimental data of each response as follows; $Y_{k}=\beta_{k 0}+\sum_{i=1}^{n} \beta_{k i} x_{i}+\sum_{i=1}^{n} \beta_{k i} x_{i}^{2}+\sum_{i=1}^{n-1} \sum_{i=1}^{n} \beta_{k j} x_{i} x_{j}$ Where, $Y_{k}=$ response variable; $Y_{1}=$ Biscuit's spread ratio $(\mathrm{mm}) ; Y_{2}=$ Fiber content (\%); $Y_{3}=$ Biscuit's breaking strength $(\mathrm{N}) ; Y_{4}=$ overall acceptability. $x_{i}$ represent the coded independent variables $\left[x_{1}=\right.$ Proportion of AF in mixed flour, $x_{2}=\mathrm{SMP}, x_{3}=$ fat content $]$; $\beta_{k o}$ is the value of the fitted response at the center point of the design, $\beta_{k i}, \beta_{k i i}$ and $\beta_{k i j}$ were the linear, quadratic and cross-product regression coefficients, respectively.

\subsection{Analysis of biscuit quality parameters}

\section{Spread ratio}

Diameter (D) and thickness (T) of baked biscuits were measured using digital Vernier caliper and determined as ratio of diameter and thickness (Okpala et al., 2013).

\section{Breaking strength}

Breaking strength of baked biscuits evaluated through heavy duty platform/Warner Bratzler (HDP/BS) probe of T2i

Table 2. Level of base material to form composite mix in coded and un-coded form.

\begin{tabular}{|c|c|c|c|c|c|c|c|}
\hline \multirow{2}{*}{ Variables } & \multirow{2}{*}{ Units } & \multirow{2}{*}{ Symbol } & \multicolumn{5}{|c|}{ Levels in coded form } \\
\hline & & & -1.682 & -1 & $\mathbf{0}$ & +1 & +1.682 \\
\hline AF & $\mathrm{g} / 100 \mathrm{~g}$ & $\mathrm{X} 1$ & 26.6 & 30 & 35 & 40 & 43.4 \\
\hline SMP & $\mathrm{g} / 100 \mathrm{~g}$ & $\mathrm{X} 2$ & 3.3 & 4 & 5 & 6 & 6.7 \\
\hline Fat & $\mathrm{g} / 100 \mathrm{~g}$ & $\mathrm{X} 3$ & 31.3 & 34 & 38 & 42 & 44.7 \\
\hline
\end{tabular}

AF: amaranth flour; SMP: Skim milk powder.

Table 3. Central composite design with experimental values of responses against variables.

\begin{tabular}{|c|c|c|c|c|c|c|c|}
\hline \multirow[b]{2}{*}{ S No } & \multicolumn{3}{|c|}{ Independent Variables } & \multicolumn{4}{|c|}{ Responses } \\
\hline & $\begin{array}{c}\text { AF } \\
(\mathrm{g} / 100 \mathrm{~g} \text { premix })\end{array}$ & $\begin{array}{c}\text { SMP } \\
(\mathrm{g} / 100 \mathrm{~g} \text { composite } \mathrm{mix})\end{array}$ & $\begin{array}{c}\text { Fat } \\
(\mathrm{g} / 100 \mathrm{~g} \text { composite } \mathrm{mix})\end{array}$ & $\begin{array}{l}\text { Breaking strength } \\
(\mathrm{N})\end{array}$ & $\begin{array}{l}\text { Spread } \\
\text { Ratio }\end{array}$ & $\begin{array}{c}\text { Fiber } \\
(\%)\end{array}$ & OA \\
\hline 1 & 30 & 4 & 34 & 79.37 & 3.75 & 7.41 & 4 \\
\hline 2 & 40 & 4 & 34 & 90 & 3.45 & 11 & 6 \\
\hline 3 & 30 & 6 & 34 & 56.35 & 3.78 & 7.77 & 6.2 \\
\hline 4 & 40 & 6 & 34 & 100 & 4 & 10.58 & 7 \\
\hline 5 & 30 & 4 & 42 & 50 & 4.4 & 7.31 & 6 \\
\hline 6 & 40 & 4 & 42 & 21 & 4 & 9.96 & 7.7 \\
\hline 7 & 30 & 6 & 42 & 39.04 & 4.15 & 7 & 6 \\
\hline 8 & 40 & 6 & 42 & 30.86 & 4.59 & 10.02 & 6 \\
\hline 9 & 26.6 & 5 & 38 & 55.2 & 4.37 & 6.84 & 5 \\
\hline 10 & 43.4 & 5 & 38 & 40.02 & 4.09 & 11.72 & 7 \\
\hline 11 & 35 & 3.3 & 38 & 39.22 & 3.68 & 9.93 & 6 \\
\hline 12 & 35 & 6.7 & 38 & 53.18 & 3.79 & 9.56 & 7 \\
\hline 13 & 35 & 5 & 31.3 & 110 & 3.4 & 9.81 & 5.5 \\
\hline 14 & 35 & 5 & 44.7 & 35.2 & 4.6 & 9.22 & 6.15 \\
\hline 15 & 35 & 5 & 38 & 48.67 & 3.49 & 9.48 & 6 \\
\hline 16 & 35 & 5 & 38 & 47.33 & 3.6 & 10.21 & 6 \\
\hline 17 & 35 & 5 & 38 & 55.71 & 3.56 & 9.56 & 6 \\
\hline 18 & 35 & 5 & 38 & 48.8 & 3.45 & 9.02 & 5.8 \\
\hline 19 & 35 & 5 & 38 & 49.76 & 3.48 & 9 & 5.9 \\
\hline 20 & 35 & 5 & 38 & 40.26 & 3.65 & 9.36 & 6 \\
\hline
\end{tabular}

AF: amaranth flour; SMP: Skim milk powder. 
texture analyzer (TA). Individual sample of biscuit placed on to the flat platform in such a manner that they were supported in the central axis and get punctured from middle. Pre-calibration of instrument was carried out with $5 \mathrm{~kg}$ weight and each test sample was evaluated in 6 replicates. TA setting was kept to: Pre-test speed of $2 \mathrm{~mm} / \mathrm{s}$, Test speed of $3 \mathrm{~mm} / \mathrm{s}$; Post-test speed of $10 \mathrm{~mm} / \mathrm{s}$ (Hooda \& Jood., 2005). This test simulates the evaluation of biscuit hardness by holding the same in hand and breaking through bending and also through first bite in mouth.

\section{Crude fiber content}

Extraction and quantification of \% crude fat from biscuits was carried out with socsplus of Pelican Instruments from Chennai where fine crushed powder was allowed to react with petroleum ether $\left(40-60^{\circ} \mathrm{C}\right)$ for about $45 \mathrm{~min}$ at $180^{\circ} \mathrm{C}$. Calculated amount of fat free powder $(\mathrm{W})$ obtained was followed for crude fiber estimation through fibraplus of Pelican Instruments from Chennai where it was treated with $1.25 \% \mathrm{H}_{2} \mathrm{SO}_{4}(150 \mathrm{ml})$ followed by its washing with distilled water to remove the acid residue adhered with the digested material. Then treated with $1.25 \% \mathrm{NaOH}(150 \mathrm{ml})$ and finally washed away the alkali residue with distilled water. Each cycle of acid and alkali digestion takes about $45 \mathrm{~min}$. Washed residue were kept in hot air oven for drying untill constant weight $\left(\mathrm{W}_{1}\right)$ was obtained, which is then incinerated in muffle furnace at $550{ }^{\circ} \mathrm{C}$ for $5 \mathrm{~h}$ so that they get burnt into ashes. Weight $\left(\mathrm{W}_{2}\right)$ was taken after it gets cooled \& calculated using formula (Singh \& Hathan, 2014). Crude fiber content $(\%)=\frac{\left(\mathrm{W}_{1}-\mathrm{W}_{1}\right)}{(\mathrm{W})} \mathrm{X} 100$.

\section{Overall acceptability}

Liking preferences for optimized baked biscuit were evaluated on the basis of 9-point hedonic scale by group of individuals against color, appearance, flavor and mouthfeel as overall acceptability criteria. Biscuits were presented in coded form and evaluated during 10-11.30 am.

\section{Results and discussion}

Effect of varying levels of amaranth flour, SMP and fat content on selected set of quality parameters viz. spread ratio, breaking strength, fiber content and overall acceptability was studied (Table 3). This data was fitted to second order polynomial model followed by analysis of variance (ANOVA) (Table 4). High $\mathrm{R}^{2}$ value indicates that experimental data well explained by the model. Similarly high value for adjusted determination coefficient i.e. adjusted $\mathrm{R}^{2}$ advocate high significance of the model and indicated that second order terms were sufficient (Liu \& Wang, 2007).

\subsection{Breaking strength}

Breaking strength of biscuits is a factor that defines how they work when placed in mouth and pressed in between the teeth; moderate crackling strength and crispy mouthfeel are the key factors that validate the level of acceptability by consumers. Reasonable intensity of breaking strength is the practical characteristic operated through \% proportion of fat and moisture utilized in biscuit preparation before baking. Later on acquired moisture during storage resulted in sogginess of same which alters mouthfeel, lower breaking strength values and hence the acceptability. Magnitude of $\mathrm{p}$-value indicates that all variables shown to have significant effect and their quadratic effect also lie at $5 \%$ level of significance $(\mathrm{p}<0.05)$ for biscuit's breaking strength.

It is predicted from the $\beta$-coefficient values of fat and amaranth (Table 4) that do not support to enhance breaking strength, whereas SMP shown to have positive effect in its contribution to provide appropriate hardness to the baked biscuits (Figure 1). Biscuits with fat \% in mix to a certain limit contribute to the development of hollow network with porosity thus reduced biscuit's breaking strength. Increase in its level otherwise shifts the prepared dough to irregular lump as melted thin scrap that are much friable and does not find any role to feel crunchy mouthfeel effect (Figure 2) (Schober et al., 2003). Parallel preparations with low fat level resulted in biscuit with chewy texture (Zoulias et al., 2002). SMP causes agglomeration of flour component appropriately; decided for network development similarly as evaluated by Pareyt et al. (2009).

Table 4. Regression coefficeints of diffferent responses of biscuit with their significant level.

\begin{tabular}{|c|c|c|c|c|}
\hline Responses Interaction & Breaking strength $(\mathrm{N})$ & Spread Ratio & Fiber (\%) & Overall acceptability \\
\hline Intercept (coefficient estimate) & 48.34 & 3.54 & 9.46 & 5.95 \\
\hline A & -0.615 & -0.037 & $1.484^{\star *}$ & $0.575^{* *}$ \\
\hline B & 0.6849 & $0.081^{*}$ & -0.068 & $0.232^{* *}$ \\
\hline $\mathrm{C}$ & $-22.744^{* *}$ & $0.31^{\star *}$ & -0.253 & $0.263^{* *}$ \\
\hline $\mathbf{A B}$ & $6.729^{*}$ & $0.17^{\star *}$ & -0.051 & $-0.362^{\star *}$ \\
\hline $\mathrm{AC}$ & $-11.43^{* *}$ & 0.015 & -0.0912 & $-0.14^{\star \star}$ \\
\hline BC & 1.489 & -0.030 & -0.024 & $-0.612^{\star *}$ \\
\hline $\mathbf{A}^{2}$ & 0.225 & $0.24^{\star *}$ & -0.19 & 0.017 \\
\hline $\mathbf{B}^{2}$ & -0.273 & $0.069^{*}$ & -0.026 & $0.193^{* *}$ \\
\hline $\mathrm{C}^{2}$ & $9.06^{* *}$ & $0.16^{* *}$ & -0.11 & -0.045 \\
\hline Model (F-value) & 25.36 & 28.01 & 13.94 & 78.05 \\
\hline Lack of fit (F-value) & 2.46 & 2.70 & 1.57 & 3.48 \\
\hline
\end{tabular}

${ }^{\star}$ Significant at $5 \%$ level $(\mathrm{p}<0.05) ;{ }^{*}$ Significant at $1 \%$ level $(\mathrm{p}<0.01)$. 


\subsection{Spread ratio}

Dimension of biscuit (thickness and diameter) is utmost important sensory parameter that alters the consumer behavior for their preferences. Here, the values for spread factors exist within the range of $3.4 \mathrm{~mm}$ to $4.6 \mathrm{~mm}$ (Table 3 ). p-value indicate that linear term of all the variables are significant and quadratic effect for fat also found significant at $5 \%$ level of significance.

Magnitude of $\beta$-coefficients (Table 4 ) revealed that the linear term of fat and SMP influence spread factor positively (Figure 3) whereas increased proportion of AF in composite mix decreases spreadability of baked sample (Sindhuja et al., 2005). While increase in biscuit's spread ratio is directly in concerned with the increased mobility of the system provided by the melted fat. Phase reversion from solid to liquid i.e. solid mass of fat changes to liquid oil on attaining melting point at baking temperature enhances the spreadability of biscuits with homogeneity in the same sense as studied and reported by Sudha et al. (2007).

$\%$ contribution of SMP in favoring the spread characteristics of baked biscuit works only when subjected to thermal application, where on attaining $\mathrm{T}_{\mathrm{g}}$ value (Glass transition temperature) of lactose increases spread factor of baked biscuits due to shift in amorphous to crystalline or glassy state of lactose (Larrea et al., 2005). In actual the spread mechanism in biscuit is a function of available liquid state.

\subsection{Fiber content}

Fibers are the major concern in eatables that are meant to define their functional potential. $\beta$ - coefficient value of amaranth implies that incorporation of amaranth flour contribute fiber in final baked sample. Fat or shortening behaves altogether opposite to that of amaranth, means they have none in their constituents like fiber thus responses unaffected on addition or removal of it. Likewise, SMP where protein and lactose work as its sole constituents and contribute none to elevate fiber proportion in baked goods (Bourdon et al., 2001). Availability of lactose and protein (SMP) of milk work to decide other physical and sensory characteristics rather than to influence fiber in any sense (Alvarez-Jubete et al., 2004).

\subsection{Overall acceptability}

Cumulative effect of all physical attributes finds their way to likeness of produce, studied here. Magnitude of $\mathrm{p}$-value indicates that all linear terms have significant effect at 5\% level of significance $(\mathrm{p}<0.05)$ on biscuit's overall acceptability.

Magnitude of $\beta$-coefficients revealed that AF have the maximum positive effect (0.58) followed by fat (0.26) and SMP (0.23) on biscuit's overall acceptability. Overall acceptability terms emphasized much with raised level of AF mainly because of pale yellow to golden brown color of biscuits that enhances appealability of product and soothy taste of baked biscuits (Sindhuja et al., 2005). Within the selected and applied range of SMP, overall acceptability of baked biscuit increases in terms of appealability and flavor generation due to caramelized lactose
(Figure 4); augment the color and sweetness of baked biscuits (Drake et al., 2003).

Fat is the next governing factor for liking preferences of baked good (Figure 5) meant to decide overall acceptability. Crispiness is a function owe to fat, tender mouth feel, take less melting time in mouth and have good flavor. Higher content of

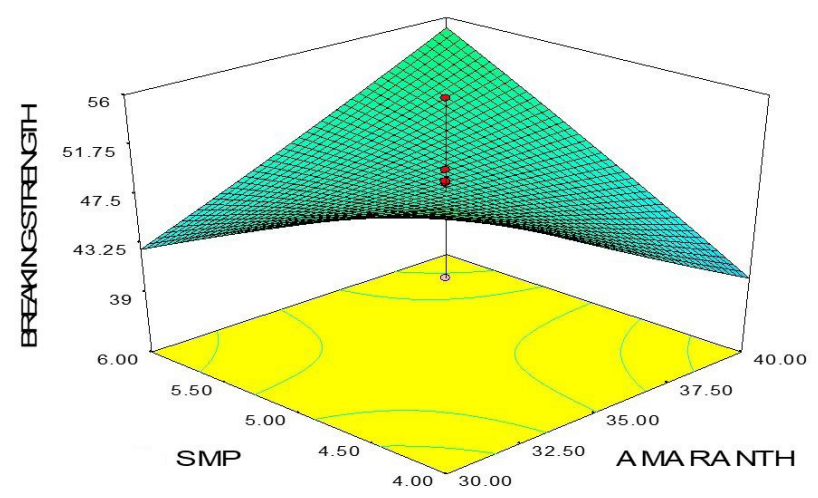

Figure 1. Effect of SMP (Skim milk powder) and amaranth on breaking strength of biscuit.

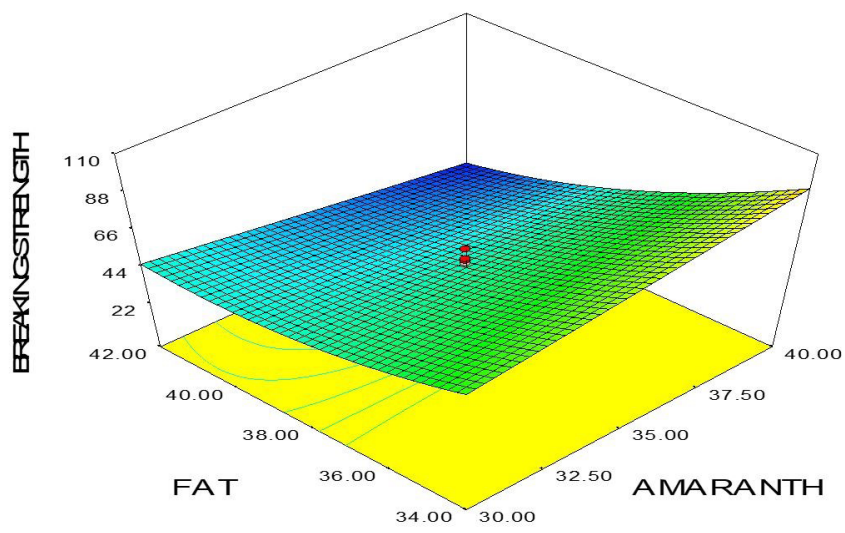

Figure 2. Effect of FAT and amaranth on breaking strengths of biscuit.

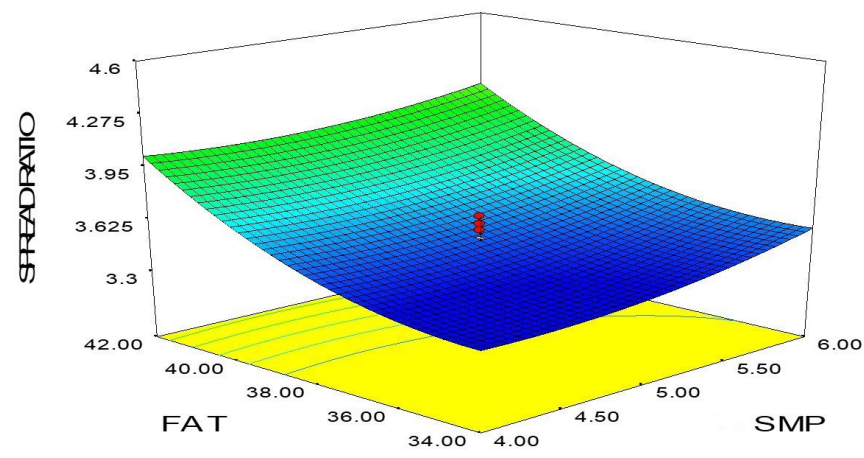

Figure 3. Effect of FAT and SMP (Skim milk powder) on spread ratio of biscuit. 


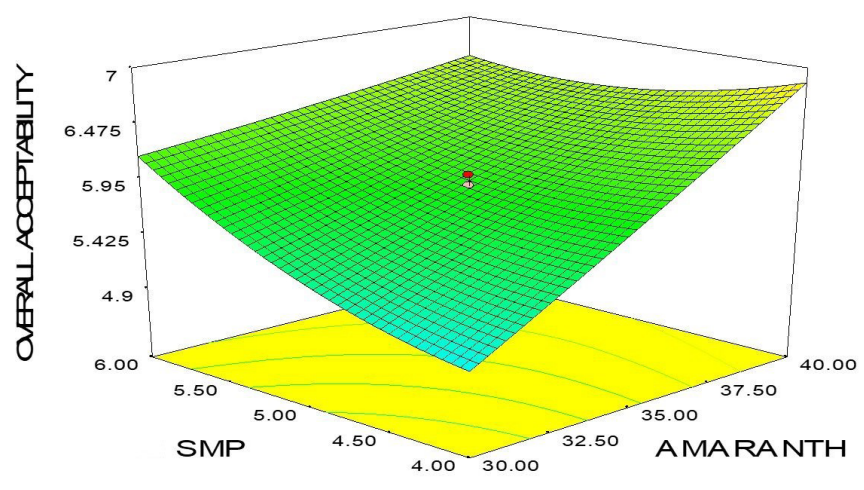

Figure 4. Effect of SMP (Skim milk powder) and amaranth on overall acceptability of biscuit.

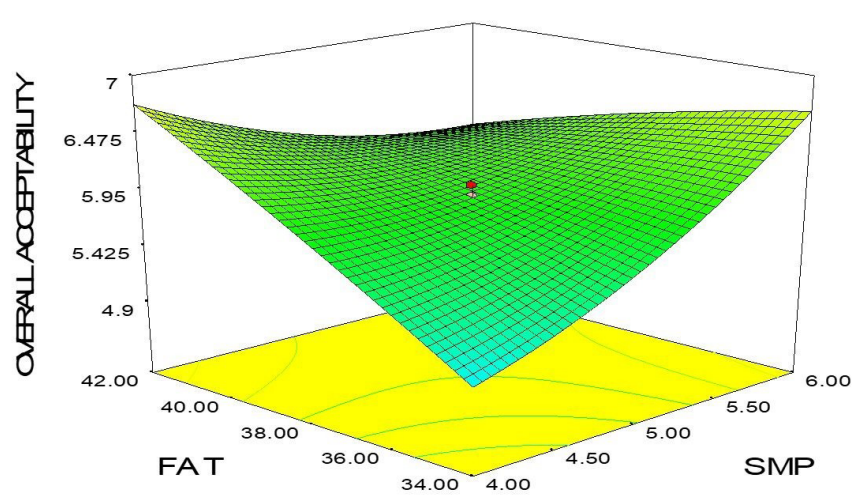

Figure 5. Effect of FAT and SMP (Skim milk powder) on overall acceptability of biscuit.

the bakery fat leads to tender mouth feel of biscuits (Khouryieh \& Aramouni, 2012).

\subsection{Optimization}

Optimization of formulation for preparation of gluten free biscuit was done to have desired response values. Independent variables were kept in range as predicted through CCRD against dependent variables recorded in terms of hardness, crude fiber, spread ratio and overall acceptability. Numerical optimization was applied to the selected ranges of amaranth flour (30-40\%), skim milk powder (4-6\%) and bakery fat (32-42\%). The optimized formulation of composite mix was found to be $40 \%, 4 \%$ and $42 \%$ of AF, SMP and fat respectively with overall desirability of 0.794 . Predicted values for breaking strength $(13.65 \mathrm{~N})$, crude fiber $(10.41 \%)$, spread ratio (4.07) and overall acceptability (7.55) executed practically and found to be competitively close to the experimental values of $14.11 \mathrm{~N}, 10.29 \%, 4.01$ and 7.05 respectively. This corroboration between predicted and estimated value inferred the fitted model suitability used to optimize the gluten free biscuit production.

\section{Conclusion}

Optimization of industrial by-product (copra meal flour), foxtail millet and pseudocereal (amaranth) composite to form gluten free mix and then its standardization for biscuit preparation is a new approach for celiac sufferers. All the selected ingredients are easily accessible and are in approach of every income population with potential attributes. Adjustment of all these ingredients with varied characteristics through central composite rotatable design (Design Expert 7) is itself a new way of finding the possibility for human utilization of these healthier grains rather than their ignorance or restricted access to animals only. Hence biscuits were optimized, tested and analysed for given set of experimental responses and were found within the predicted range using standard protocols. Sequential approach to get numerically optimized solution shown to have composite mix with proportion of $40 \%, 4 \%$ and $42 \%$ of amaranth flour, SMP and fat respectively. Most importantly overall acceptability contributed maximally with rise in amaranth and fat owe to appropriate spread ratio and breaking strength.

\section{References}

Achayuthakan, P., \& Suphantharika, M. (2008). Pasting and rheological properties of waxy corn starch as affected by guar gum and xanthan gum. Carbohydrate Polymers, 71(1), 9-17. http://dx.doi.org/10.1016/j. carbpol.2007.05.006.

Alvarez-Jubete, L., Arendt, E. K., \& Gallagher, E. (2004). Nutritive value of pseudocereals and their increasing use as functional gluten-free ingredients. Trends in Food Science \& Technology, 21(2), 106-113. http://dx.doi.org/10.1016/j.tifs.2009.10.014.

Anju, T. Jr., \& Sarita, S. (2010). Suitability of foxtail millet (Setaria italica) and barnyard millet (Echinochloa frumentacea) for development of low glycemic index biscuits. Malaysian Journal of Nutrition, 16(3), 361-368. PMid:22691989.

Arancon, R. N. (1999). Coconut flour. Cocoinfo International, 6(1), 1-8.

Awika, J. M., \& Rooney, L. W. (2004). Sorghum phytochemicals and their potential impact on human health. Phytochemistry, 65(9), 1199-1221. http://dx.doi.org/10.1016/j.phytochem.2004.04.001. PMid:15184005.

Bourdon, I., Olson, B., Backus, R., Richter, B. D., Davis, P. A., \& Schneeman, B. O. (2001). Beans, as a source of dietary fiber, increase Cholecystokinin and Apolipoprotein $B 48$ response to test meals in men. The Journal of Nutrition, 131(5), 1485-1490. http://dx.doi. org/10.1093/jn/131.5.1485. PMid:11340104.

Bressani, R., \& Garcia-Vela, L. A. (1990). Protein fractions in amaranth grain and their chemical characterization. Journal of Agricultural and Food Chemistry, 38(5), 1205-1209. http://dx.doi.org/10.1021/ jf00095a010.

Curic, D., Novotni, D., Tusac, D., Baumen, I., \& Gabric, D. (2007). Gluten free bread production by the corn meal and soybean flour extruded blend usage. Agriculturae Conspectus Scientificus, 72(3), 227-232.

Drake, M. A., Karagul-Yuceer, Y., Cadwallader, K. R., Civille, G. V., \& Tong, P. S. (2003). Determination of sensory attributes of dried milk powders and dairy ingredients. Journal of Sensory Studies, 18(3), 199-216. http://dx.doi.org/10.1111/j.1745-459X.2003.tb00385.x.

Gallagher, E., Gormley, T. R., \& Arendt, E. K. (2004). Recent advances in the formulation of gluten free cereal based products. Trends in Food Science \& Technology, 15(3), 143-152. http://dx.doi.org/10.1016/j. tifs.2003.09.012.

Hathan, B. S., \& Prassana, B. L. (2011). Optimization of fiber rich glutenfree biscuit formulation by response surface methodology. World Academy of Science, Engineering and Technology, 5(12), 893-902.

Hooda, S., \& Jood, S. (2005). Organoleptic and nutritional evaluation of wheat biscuits supplemented with untreated and treated fenugreek 
flour. Food Chemistry, 90(3), 427-435. http://dx.doi.org/10.1016/j. foodchem.2004.05.006.

Khouryieh, H., \& Aramouni, F. (2012). Physical and sensory characteristics of biscuits prepared with flaxseed flour. Journal of the Science of Food and Agriculture, 92(11), 2366-2372. http://dx.doi.org/10.1002/ jsfa.5642. PMid:22419245.

Kim, J. S., Hyun, T. K., \& Kim, M. J. (2011). The inhibitory effects of ethanol extracts from sorghum, foxtail millet and proso millet on $\alpha$-glucosidase and $\alpha$-amylase activities. Food Chemistry, 124(4), 1647-1651.

Lai, H. M., \& Lin, T. C. (2006). Bakery products: science and technology (pp. 3-65). USA: Blackwell Publishing. http://dx.doi. org/10.1002/9780470277553.ch1.

Larrea, M. A., Chang, Y. K., \& Martinez-Bustos, B. F. (2005). Some functional properties of extruded orange pulp and its effect on the quality of biscuits. Lebensmittel-Wissenschaft + Technologie, 38(3), 213-220. http://dx.doi.org/10.1016/j.lwt.2004.05.014.

Liu, G., \& Wang, X. L. (2007). Optimization of critical medium components using response surface methodology for biomass and extracellular polysaccharide production by Agaricus blazei. Applied Microbial Biotechnology, 74(1), 78-83. http://dx.doi.org/10.1007/ s00253-006-0661-6. PMid:17086412.

Makharia, G. K., Verma, A. K., Amarchand, R., Bhatnagar, S., Das, P., Goswami, A., Bhatia, V., Ahuja, V., Datta Gupta, S., \& Anand, K. (2011). Prevalence of celiac disease in the northern part of India: a community based study. Journal of Gastroenterology and Hepatology, 26(5), 894-900. http://dx.doi.org/10.1111/j.1440-1746.2010.06606.x. PMid:21182543.

Moorthy, M., \& Visswanathan, K. (2009). Nutritive value of extracted coconut (Cocos nucifera) meal. Research Journal of Agriculture and Biological Sciences, 5(4), 515-517.

Okpala, L., Okoli, E., \& Udensi, E. (2013). Physico-chemical and sensory properties of cookies made from blends of germinated pigeon pea, fermented sorghum, and cocoyam flours. Food Science \& Nutrition, 1(1), 8-14. http://dx.doi.org/10.1002/fsn3.2. PMid:24804009.

Pareyt, B., Talhaoui, F., Kerckhofs, G., Brijs, K., Goesaert, H., Wevers, M., \& Delcour, J. A. (2009). The role of sugar and fat in sugar-snap biscuits: Structural and textural properties. Journal of Food Engineering, 90(3), 400-408. http://dx.doi.org/10.1016/j.jfoodeng.2008.07.010.
Saturni, L., Ferretti, G., \& Bacchetti, T. (2010). The gluten-free diet: safety and nutritional quality. Nutrients, 2(1), 16-34. http://dx.doi. org/10.3390/nu2010016. PMid:22253989.

Schober, T. J., O’Brien, C. M., McCarthy, D., Darnedde, A., \& Arendt, E. K. (2003). Influence of gluten free flour mixes and fat powders on the quality of gluten free biscuits. European Food Research and Technology, 216(5), 369-376. http://dx.doi.org/10.1007/s00217003-0694-3.

Sindhuja, A., Sudha, M. L., \& Rahim, A. (2005). Effect of incorporation of amaranth flour on the quality of biscuits. European Food Research and Technology, 221(5), 597-601. http://dx.doi.org/10.1007/s00217005-0039-5.

Singh, A., \& Hathan, B. S. (2014). Comparative characterization of foxtail millet, physico-chemical approach for its suitability to celiacs. Journal of Food Processing \& Technology, 5, 1-4.

Singh, A., \& Kumar, P. (2018). Gluten free approach in fat and sugar amended biscuits: a healthy concern for obese and diabetic individuals. Journal of Food Processing and Preservation, 42(3), e13546. https:// doi.org/10.1111/jfpp.13546.

Siró, I., Kápolna, E., Kápolna, B., \& Lugasi, A. (2008). Functional food. Product development, marketing and consumer acceptance-a review. Appetite, 51(3), 456-467.http://dx.doi.org/10.1016/j.appet.2008.05.060. PMid:18582508.

Srivastava, Y. (2010). Effect of virgin coconut meal (VCM) on the textural, thermal and physico chemical properties of biscuits. Food and Nutrition Sciences, 1(2), 38.

Sudha, M. L., Vetrimani, R., \& Leelavathi, K. (2007). Influence of fiber from different cereals on rheological characteristics of wheat flour dough on biscuit quality. Food Chemistry, 100(4), 1365-1370. http:// dx.doi.org/10.1016/j.foodchem.2005.12.013.

Valentina, S., Paul, A., Andrew, P., \& Senol, I. (2010). The advantage of using extrusion processing for increasing dietary fiber level in gluten free products. Food Chemistry, 12(1), 156-164.

Whelton, P. K., He, J., Cutler, J. A., Brancati, F. L., Appel, L. J., Follmann, D., \& Klag, M. J. (1997). Effects of oral potassium on blood pressure. Journal of the American Medical Association, 277(20), 1624-1632. http://dx.doi.org/10.1001/jama.1997.03540440058033. PMid:9168293.

Zoulias, E. I., Oreopoulou, V., \& Tzia, C. (2002). Textural properties of low fat cookies containing carbohydrate- or protein based fat replacers. Journal of Food Engineering, 55(4), 337-342. http://dx.doi. org/10.1016/S0260-8774(02)00111-5. 